\title{
レーザー安全講習
}

\author{
永井茂之 \\ 研修·安全講習委員会 \\ 永井歯科診療室
}

（受付： 2021 年 1 月 29 日，受理：2021 年 2 月 26 日)

\section{Laser Safety Course}

\author{
Shigeyuki NAGAI \\ Committee of Clinical and Safety Training Program in Japanese Society for Laser Dentistry \\ Nagai Dental Clinic
}

(Received: January 29, 2021, Accepted for Publication: February 26, 2021)

\begin{abstract}
The Japanese National Insurance has covered the laser treatment for recurrent aphthous stomatitis since 2018. It is very important to understand the rule of insurance and also the novel technics for the treatment of recurrent aphthous stomatitis with laser application. The Japanese Ministry of Health, Labor and Welfare ask to refer for this laser treatment to the "Basic concept for the treatment of the recurrent aphthous stomatitis with laser application" which was distributed by the Japanese Association for Dental Science in 2018. The safety management in laser dentistry based on "Basic concept for the treatment of the recurrent aphthous stomatitis with laser application” will be clear in this article.
\end{abstract}

(J. Jpn. Soc. Laser Dent. $31: 2 \sim 5,2021$ Reprint requests to Dr. NAGAI)

Key words $=$ Laser safety, Recurrent aphthous stomatitis, Laser treatment

キーワードニレーザー安全, 再発性アフタ性口内炎, レーザー治療

\section{安全講 習}

第 11 回歯科用レーザー教育研修会の延期を受け, 担当 講演である安全教育研修を誌上で行うこととなった。編集 委員会から「レーザー応用による再発性アフタ性口内炎治 療に関する基本的な考え方」を元に安全講習を, という依 頼である。「レーザー応用による再発性アフタ性口内炎治 療に関する基本的な考え方」は平成 30 年に日本歯科医学 会が配布した資料であり, 日本歯科医学会のホームページ で“歯科診療に関する基本的な考え方”, “平成 30 年”で確 認出来る。厚労省の定める歯科保健診療の項目でこの 「レーザー応用による再発性アフタ性口内炎治療に関する 基本的な考え方」が引用されている。保険収載された“口 腔粘膜処置”は下記の通りである。

\section{I029-3 口腔粘膜処置（1口腔につき）}

別に厚生労働大臣が定める施設基準に適合している ものとして地方厚生局長等に届け出た保険医療機関 において，レーザー照射により当該処置を行った場
合に算定する。ただし，2回目以降の口腔粘膜処置の 算定は, 前回算定日から起算して 1 月経過した日以 降に行った場合に限り，月 1 回に限り算定する。

（1）口腔粘膜処置は，別に厚生労働大臣が定める施 設基準に適合しているものとして地方厚生（支）局 長に届け出た保険医療機関において, 再発性アフタ 性口内炎の小アフタ型病変に対してレーザー照射を 行った場合に 1 月につき 1 回に限り算定する。なお, 当該処置の実施にあたっては「レーザー応用による 再発性アフタ性口内炎治療における基本的考え方」 (平成 30 年 3 月日本歯科医学会) を参考にすること。 （2）前回算定した日の属する月に前回照射した部位 と異なる部位に生じた再発性アフタ性口内炎に対し て当該処置を実施した場合の費用は, 所定点数に含 まれ，別に算定できない。

（3）レーザー照射を行った場合は，病変の部位及び 大きさ等を診療録に記載すること。

干 141-0031 東京都品川区西五反田 8-1-14 最勝ビル 1F TEL 03-3490-8241

Saisho Build. 1F, 8-1-14 Nishigotanda, Shinagawa-ku, Tokyo 141-0031, Japan. TEL +81-3-3490-8241 
厚労省が定めている様に, 上記の処置にあたっては 「レーザー応用による再発性アフ夕性口内炎治療に関する 基本的な考元方」(平成 30 年 3 月日本歯科医学会) を参考 にすることが求められている。日本歯科医学会の発信して いる “歯科診療に関する基本的な考え方”とは，臨床にお いて適切な診断と治療を支援することを目的として, 診 断・治療等, 診療の内容等についての最新の情報を, 日本 歯科医学会がまとめたものである。簡潔に申し上げると, 「レーザー応用による再発性アフ夕性口内炎治療に関する 基本的な考元方」(平成 30 年 3 月日本歯科医学会) は非常 に良く出来ている。下記に全文を記すので，大いに参考に されたい。

\section{「レーザー応用による再発性アフタ性口内炎治療に 関する基本的な考元方」の問題点}

\section{1. 使用機器について}

この「レーザー応用による再発性アフ夕性口内炎治療に 関する基本的な考え方」（以下「指針」と表記する）は先 に記した様に詳細まで網羅されている。しかしながら，保 険収載を見越してなのか, 健康保険診療に寄っている傾向 がある。本来歯科医学の立場から治療に対する考方方を記 しているはずであるが, 大項目 5 , “使用機器とその使用 方法について”で，“国内に挸いて承認されている $\mathrm{Nd}: \mathrm{YAG}$ レーザー, Er:YAG レーザー, $\mathrm{CO}_{2}$ レーザー, 半導体レー ザー機器”とあるが，もち万ん国内に扔いて承認されてい る機器でなくても良い。これらの機器には“保険診療で使 用する場合は，保険適用となっている機器に限る”という 注釈が必要である。大項目 2 , では補記されているので, 字数の関係で削除されたのかもしれない。また, 再発性ア フタ性口内炎に使用するレーザー機器は上記の機器に限ら ない。上記の 4 波長は再発性アフ夕性口内炎の焼灼に用い られ, その結果として疼痛緩和と早期治癒を期待するもの であるが，いわゆるソフトレーザー（レーザークラスが 4 未満に分類される）は疼痛緩和および潰瘍の早期治癒を目 的としたレーザー治療機器の王道であることを忘れてはな らない。

\section{2. 安全管理について}

この「指針」は臨床において適切な診断と治療を支援す ることを目的として, 診断・治療等, 診療の内容等につい ての最新の情報を日本歯科医学会がまとめたものである。 故に, 記述は歯科医師に向けられており，その記述内容は 非常に有用である。保護ゴーグルの使用や試験照射, 安全 に留意した照射方法等の必要な情報が網羅されている。し かしながらレーザーの安全管理は歯科医師のみで担保され るものではなく, 厚労省がレーザー安全管理者の選定・任 命を義務付けているのは承知の通りである。レーザー安全
管理者の責務を記述する必要はないが, 施術者（歯科医 師）はレーザー安全管理者の管理下で処置を行う，〈らい の記述はあっても良かったかもしれない。

\section{3. 実際の治療について}

この「指針」の “実際の治療方法”の記述は非常によく まとまっており，しかもレーザー治療時に起こりうる事故 の予防にも留意されている。是非参考にして頂きたい。し かしながら, “1 回の照射で”, という表現に戸惑う術者も いるのではないか。各波長, 各レーザー機器で適切なパラ メーターを設定する事の重要性は十分記述されてはいるも のの, 組織の過熱を回避する目的で数回の間欠的な照射を 試みている術者は多いはずである。これに関しては本特集 の各論を参照されたい。

\section{4. レーザー照射による有害事象について}

ここに記述されている内容は, 再発性アフタ性口内炎治 療にレーザーを使用した場合に特に考えられる有害事象で あり（気腫の発生予防は基本的な注意事項ではあるが）, 簡潔に要約されている。しかしながら，レーザー安全管理 の立場から患者の有害事象で最も留意されるべき事の一つ は眼の損傷である。レーザー機器の安全基準は眼に及ぼす 障害の程度による基準であることを十分に認識しておきた い所である。

\section{レーザー応用による再発性アフタ性口内炎治療に 関する基本的な考え方}

(平成 30 年 3 月 日本歯科医学会)

1. はじめに

レーザー医療機器の使用により, 再発性アフタ性口内炎 に対する低侵襲かつ安全な治療が期待できる。口腔粘膜処 置における再発性アフタ性口内炎のレーザー照射を適切に 行う必要があることから，この基本的な考え方を作成する こととし，その概要について説明する。

なお，この基本的な考え方を作成するにあたり，用語 は, 日本歯科医学会編「日本歯科医学会学術用語集」に準 拠した。

\section{2. レーザー照射療法の対象疾患}

口腔粘膜処置における対象病変は，レーザー照射を利用 した再発性アフ夕性口内炎（小アフ夕型）で, 悪性潰瘍性 病変が否定されるものに限る（保険診療で使用する場合 は，保険適用となっている機器に限る)。

\section{3. 再発性アフタ性口内炎の臨床所見と治療法}

アフタの再発を繰り返す口腔粘膜の炎症を再発性アフタ 性口内炎（Recurrent Aphthous Stomatitis）という。臨 
床的には, 小アフタ型, 大アフタ型, 疮疹状潰瘍型の 3 型 に分類される。

対処法としては, 局所の刺激を避け, 口内炎パッチの貼 付, ステロイド含有軟膏塗布, 含嗽, 鎮痛薬, 漢方薬, 活 性型ビタミン B 2 製剤投与など薬物療法㧍よび口腔内を清 潔に保つことなどが一般的であるが，しばしば接触痛を伴 うため, 摂食・会話など口腔諸機能の低下が罹患患者に とって大きな課題である。

レーザー照射療法により, 照射部位表面付近の組織に直 接作用し, 疼痛に対して即時的な鎮痛効果が得られ持続さ れるものである。

\section{4. 再発性アフタ性口内炎の臨床的特徵}

小アフ夕型は, 約 80 〜 90\%と最も多い頻度であるとさ れ, 径が $5 \mathrm{~mm}$ くらいの浅い潰瘍をいう。潰瘍の個数は 1 〜 個程度で, 症状は軽く㓔痕を残さずに $7 \sim 14$ 日程度 で治癒する。発生部位は口唇, 㚘粘膜, 舌背, 舌側縁など 非角化口腔粘膜に発生する。

大アフタ型は, 潰瘍の径が $10 \mathrm{~mm}$ 以上と大きく, 角化, 非角化口腔粘膜に発生するが, 軟口蓋に発生することが多 い。潰瘍は深く, 個数は $1 \sim 3$ 個で, 治癒までの期間は 1 ケ月以上に及ぶことが多く, 疼痛が激しい。またしばし ば瘢痕を残す。

疮疹状潰瘍型は, ヘルペス性歯肉口内炎に類似した径 $1 \sim 2 \mathrm{~mm}$ の $5 \sim 20$ 個（ときに 100 個）の小潰瘍が非角 化口腔粘膜に散在性, 多発性に発生する。とくに舌腹, 口 底粘膜に生じることが多い。疮疹状潰瘍型の病変は 7 14 日程度で潰瘍は通常痏痕を残さず治癒する。

\section{5. 再発性アフタ性口内炎に対するレーザー照射療法 対象病变と鑑別診断について}

(1) 口腔軟組織における再発性アフ夕性口内炎による疼痛 があり，それにより摂食，会話など口腔機能障害がみ られるなど, 疼痛緩和および潰瘍の早期治癒を必要と する患者。

(2)対象病変は悪性潰瘍性病変が否定されるものに限る。

(3)レーザー照射は, 小アフタ型の病変が対象となる。 診断の結果, 原因が医科的疾患によるものや悪性の可 能性が疑われる場合には, 速やかに専門の医療機関へ 紹介する。

臨床的に多くみられる小アフ夕型の症例は, 口内炎発 症後 $10 \sim 14$ 日程度で自然治癒する病態であることか ら, レーザー照射後に疼痛の変化がないか, むしろ憎 悪するなど潰瘍の治癒傾向がみられなければ, 全く別 の病態の可能性も考えられるため, 漫然とレーザー照 射を繰り返し継続せずに専門の医療機関と連携する。 なお, 化学放射線治療を受けるがん患者, 造血幹細胞
移植の治療に伴い発症する口腔粘膜炎（Oral Mucositis） とは発症機序および推奨治療法が異なりレーザー照射 療法の対象とはならない。また, 口腔粘膜の慢性刺激 潰瘍性病変として裖創性潰瘍がある。本病変は不適合 義歯や鋭縁のある補綴物, う蝕の刺激に起因する潰瘍 であり，原因を除去すれば治癒するので, 再発性アフ 夕性口内炎とは異なる。

\section{レーザー機器とその使用方法について}

(1)機種: 国内において承認されている Nd:YAGレー ザー, Er:YAG レーザー, $\mathrm{CO}_{2}$ レーザー, 半導体レー ザー機器。

(2)機種の選択ならびに使用においては, レーザーの基本 的な事項を踏まえ, 表面吸収型レーザー: $\mathrm{CO}_{2}$ レー ザー Er:YAG レーザー，組織透過型レーザー：Nd:YAG レーザー 半導体レーザーの各特性, 使用上の注意, 機 器の管理, 安全性などに関して, 各機器における添付 文書に従う。

(3)レーザー機器の使用にあたっては, レーザー照射療法 に関連する安全教育研修（日本歯科医学会ならびに日 本医学会加入の関連学会主催の講習会等) の修得が望 ましい。

\section{実際の治療について}

(1)照射にあたって患者, 術者, 介助者は, レーザー波長 に対応した保護眼鏡を装着し, 眼の保護をしなければ ならない。また誤照射による口腔粘膜や皮膚の火傷に も注意する。

(2)再発性アフタ性口内炎の潰瘍にレーザー照射療法を施 行する際には，それぞれのレーザーの特性が異なるの で一律には規定し難いが, 下記の事項を遵守し慎重に 照射を行う。

i ）照射は無麻酔で行う。

ii）口腔は重要臟器に囲まれており, 神経, 血管の走 行に注意し，深部に熱影響が及ばないよう，使用 するレーザーの波長特性, 最新の添付文書を確認 し, 機器の仕様をよく理解して照射条件 (照射出 力, 照射時間, 照射モード) を選択する。

iii）使用前には試験照射（テストファイヤー）を行う。

iv）同一部位に長時間の定点照射を避ける。

v ）照射面より $3 \sim 10 \mathrm{~mm}$ 程度レーザーハンドピー スを離し, 可能な場合にはハンドピースあるいは コンタクトチップを動かしながら非焦点照射を行 うことにより熱影響を回避する。

vi）照射時の温熱感覚や疼痛, 患部の乾燥状態に注意 を払いながら過剩な照射を避ける。

vii）潰瘍表面にジェルを塗布してレーザー照射する方 
法が報告されているが，レーザー照射の影響によ

りジェルの変性があると考えられ，このような照 射方法は推奨できない。

(3) 1 回の照射で口内炎の接触痛が軽減ないし消失し, 潰 瘍は治癒傾向を呈することが多いが，必要に応じて 日を変え照射を行う。照射部位におけるアフタの個 数にかかわらず, 一連の照射回数は, 日を異にして 3 回程度とする。治癒後再度のレーザー照射を行う際 には, 前回から 1 ヶ月以上の期間を空けて同様の評 価と照射を行う。また, 再度のレーザー照射を行う 際に前回の照射条件が参考となるため照射条件 (レー ザーの種類と装置の名称，照射出力，照射時間，照 射モード（連続，パルスーパルス幅 [s]，繰返し周波 数 $[\mathrm{pps}$ あるいは $\mathrm{Hz}]$, パルスエネルギー $[\mathrm{J}]$, ピー
ク出力 $[W]$ など）を記録することが望ましい。

\section{6. レーザー照射による有害事象}

口腔領域におけるレーザー照射療法に関連する患者の有 害事象は，照射部位，周辺組織における過剩照射による熱 的損傷や空冷装置を有する装置では気腫の発生などである。

\section{利益相反}

本論文に関して開示すべき利益相反状態は無い。

\section{参考文献}

1）「レーザー応用による再発性アフ夕性口内炎治療に関する基 本的な考元方」日本歯科医学会 平成 30 年 3 月

2） I029-3 口腔粘膜処置（1口腔につき）歯科診療報酬改訂の概 要 厚生労働省 令和 2 年 3 月 5 日 